\title{
KOMUNIKASI KESEHATAN TENTANG KESEHATAN REPRODUKSI DAN SEKSUAL KOMPREHENSIF (Studi Di Youth Center Pilar Pkbi Jawa Tengah)
}

\author{
Ayu Khoirotul Umaroh ${ }^{1}$, Tri Krianto Karjoso ${ }^{2}$ \\ ${ }^{1}$ Mahasiswa Pascasarjana Fakultas Kesehatan Masyarakat, Universitas Indonesia, Indonesia \\ ${ }^{2}$ Dosen Fakultas Kesehatan Masyarakat, Universitas Indonesia, Indonesia \\ ayu.khoirotul@ui.ac.id ${ }^{1}$, tkarjoso@gmail.com ${ }^{2}$
}

\begin{abstract}
Reproductive health issues and adolescent sexuality are important studies, such as premarital sexual behavior, unwanted pregnancy, abortion, STIs, and HIV-AIDS. One of the factors that influence adolescent risky sexual behavior is knowledge. The knowledge index figure on adolescent reproductive health in Central Java is still low about 58.1\%. One of the parties that has a role in the field of adolescent reproductive health is the youth center. This research examined health communication about reproductive and sexual health at the PILAR PKBI Youth Center, Central Java. This research used a qualitative approach with a case study design. The theoretical framework used the Logic Model. Informants were determined by purposive sampling with a total of 19 people. The data collection methods were by in-depth interviews via WhatsApp and focus group discussions through Zoom meetings due to the pandemic situation. Data were analyzed with thematic analysis. The results of the research were 1) The issues are in line the CSE material; 2) The goal is to increase youth care and responsibility; 3) Inputs are the trained human resources and adequate funding sources; 4) The communication process runs with educational activities, empowerment, and counseling with strategies for the formation of peer educator, lobbying, advocacy, and collaborative activities as well as the materials and media used vary widely according to the target; 5) Communication output are the establishment of peer educators and stakeholder support; 6) The results of the communication program are knowledge, attitudes, and behavior of target adolescents that qualitatively good. The health communication carried out by PILAR and the results obtained is quite good. However, it still needs attention to be paid to increasing the capacity of volunteers and peer educators as communicants.
\end{abstract}

Keyword : Reproductive Health, Sexual Health, Health Communication, Logic Model, Adolescent

\begin{abstract}
ABSTRAK
Permasalahan kesehatan reproduksi dan seksualitas remaja merupakan kajian penting, seperti perilaku seks pranikah, kehamilan tidak diinginkan (KTD), aborsi, infeksi menular seksual (IMS), dan HIVAIDS. Salah satu faktor yang mempengaruhi perilaku seks berisiko remaja adalah pengetahuan. Angka indeks pengetahuan tentang kesehatan reproduksi remaja di Jawa Tengah masih rendah yakni 58,1\%. Salah satu pihak yang berperan di bidang kesehatan reproduksi remaja adalah youth center. Sehingga penelitian ini ingin mengkaji komunikasi kesehatan tentang kesehatan reproduksi dan seksual di Youth Center PILAR PKBI Jawa Tengah. Penelitian ini menggunakan pendekatan kualitatif dengan desain studi kasus. Kerangka teori menggunakan Logic Model. Informan ditentukan dengan purposive sampling dengan jumlah 19 orang. Metode pengambilan data dengan wawancara mendalam melalui WhatsApp dan diskusi kelompok terarah melalui Zoom meeting karena situasi pandemi. Analisis data dengan tematik analisis. Hasil penelitian yakni 1) Isu yang diangkat sesuai dengan materi CSE; 2) Tujuannya yakni meningkatkan kepedulian dan tanggung jawab remaja; 3) Input yang dimiliki SDM terlatih dan sumber dana memadai; 4) Proses komunikasi berjalan dengan aktivitas edukasi, pemberdayaan, dan konseling dengan strategi pembentukan PE, lobbying, advokasi, dan kerjasama kegiatan serta materi dan media yang digunakan sangat bervariasi disesuaikan dengan sasaran; 5) Output komunikasi yakni terbentuknyapeer educator dan dukungan stakeholder; 6) Hasil program komunikasi yakni pengetahuan, sikap, dan perilaku remaja sasaran secara kualitatif cukup baik.
\end{abstract}


Komunikasi kesehatan yang dilakukan PILAR dan hasil yang didapatkan sudah cukup baik. Namun masih perlu diperhatikan terkait peningkatan kapasitas relawan dan peer educator sebagai komunikan.

Kata Kunci : Kesehatan Reproduksi, Kesehatan Seksual, Komunikasi Kesehatan, Logic Model, Remaja

\section{PENDAHULUAN}

Permasalahan kesehatan reproduksi dan seksualitas remaja di Indonesia menjadi salah satu kajian penting. Hal ini dikarenakan munculnya implikasi yang fatal dari remaja yang tidak tahu kesehatan reproduksi dan seksualitas dengan baik dan benar, misalnya saja kehamilan di luar nikah atau bahkan aborsi. Survei dari SDKI 2017 secara nasional menunjukkan bahwa hanya $33 \%$ remaja perempuan dan $37 \%$ remaja laki-laki yang tahu dengan benar tentang masa subur, remaja usia 15-19 tahun yang mengetahui risiko kehamilan setelah sekali melakukan hubungan seksual sebanyak $50,5 \%$ pada remaja perempuan dan $48,6 \%$ pada remaja laki-laki, diskusi kesehatan reproduksi paling banyak dilakukan dengan teman, dan sumber informasi serta konseling paling banyak dari puskesmas PKPR 34,2\% sedangkan youth center hanya $2,6 \%$ (Kemenkes RI, 2017).

Perilaku seksual remaja yang berisiko dilaporkan dari survei SDKI 2017 bahwa secara nasional kebanyakan remaja perempuan dan laki-laki mengaku saat berpacaran melakukan aktivitas berpegangan tangan (64\% dan 75\%), berpelukan (17\% dan 33\%), cium bibir (30\% dan 50\%), dan meraba/diraba (5\% dan $22 \%$ ). Selain itu, $8 \%$ laki-laki dan $2 \%$ perempuan melaporkan telah melakukan hubungan seksual (Kemenkes RI, 2017). Perilaku ini akan berdampak terjadinya kasus kehamilan tidak diinginkan, penyakit kelamin menular, HIV/AIDS, serta aspek psikologi dan sosial lainya (Kasim, 2014).

Jumlah remaja di Indonesia paling banyak ada di Provinsi Jawa Barat kemudian disusul oleh Jawa Tengah. Di Provinsi Jawa Tengah, sebanyak $25,6 \%$ remaja tidak tahu tentang masa subur, $17,7 \%$ tidak tahu risiko kehamilan setelah sekali melakukan hubungan seksual dan 16,4\% mengatakan tidak dapat hamil. Remaja Jawa Tengah pernah melakukan hubungan seksual sebelum menikah sebanyak $1,7 \% \quad(2,6 \%$ pada laki-laki dan $0,6 \%$ pada perempuan). Dilaporkan bahwa angka indeks pengetahuan tentang kesehatan reproduksi remaja masih rendah, yakni sebesar $58,1 \%$ (BKKBN, 2019).

Dalam lingkup nasional, beberapa faktor teridentifikasi berhubungan dengan perilaku seksual berisiko remaja adalah tingkat pendidikan, pengetahuan, sikap, gaya hidup, sumber informasi, dan tempat tinggal dapat mempengaruhi perilaku seksual berisiko pada remaja. Hasil penelitian menyebutkan bahwa remaja dengan sikap yang tidak baik memiliki risiko 2,129 kali besar untuk melakukan seksual pranikah (Umaroh, Kusumawati and Kasjono, 2017). Penelitian lain juga menyebutkan bahwa faktor-faktor yang mempengaruhi remaja di beberapa SMA di Kota Semarang untuk melakukan perilaku seksual berisiko adalah sikap yang buruk dan paparan media sosial berkonten seksual (Naja, Agushybana and Mawarni, 2017). Selain itu, tekanan personal (46\%), tekanan sebaya (27\%), dipaksa, alkohol dan pengaruh obrolan (9\%), dan masalah ekonomi (9\%) merupakan alasan yang menyebabkan remaja melakukan perilaku seksual pranikah pertama kali (Amare, 2017).

Salah satu upaya untuk meningkatkan pengetahuan remaja terkait kesehatan reproduksi dan seksualitas supaya terhindar dari perilaku seksual berisiko adalah memberikan remaja informasi. Informasi tersebut dapat diberikan dengan cara offline maupun online. Sebuah penelitian memaparkan bahwa kader youth center yang telah dilatih untuk memberikan edukasi 
kesehatan reproduksi remaja dapat meningkatkan pengetahuan remaja sasaran dan mampu merubah sikap remaja untuk sadar pentingnya pendewasaan usia pernikahan (Azinar et al., 2018). Penelitian lain menyebutkan bahwa dengan kurangnya program pendidikan kesehatan seksual yang distandarisasi dan berbasis bukti di Amerika Serikat, masa depan pendidikan kesehatan seksual yang komprehensif sedang bergerak menuju aplikasi smartphone. Ada banyak teknologi kesehatan seksual yang menargetkan remaja, yang sebagian besar telah terbukti menunjukkan efek positif. Penggunaan aplikasi seluler, terutama untuk populasi yang rentan, bisa lebih efektif karena privasi dan penyebaran yang luas (Brayboy et al., 2018).

Informasi tersebut dapat diberikan oleh instansi pemerintah maupun pihak swasta bahkan orang tua dari remaja tersebut. Informasi yang benar dan lengkap diharapkan mampu memberikan remaja pemahaman tentang kesehatan reproduksi dan seksualitas yang baik. Salah satu pihak swasta yang memiliki kepedulian terhadap kesehatan reproduksi dan seksualitas remaja di Indonesia adalah Perkumpulan Keluarga Berencana Indonesia (PKBI). Di dalam PKBI terdapat bagiankhusus yang mengurus tentang isu remaja, yang diberikan nama youth center. PKBI sebagai Lembaga Swadaya Masyarakat (LSM) level nasional memiliki program khusus untuk remaja yakni Pusat Informasi dan Layanan Remaja (Pusat dan Informasi Layanan Remaja $P K B I$, no date). Program ini dilakukan pada setiap PKBI daerah, salah satunya adalah PKBI Daerah Jawa Tengah yang memiliki Youth Center bernama PILAR.

Memberikan informasi merupakan salah satu tujuan dari komunikasi kesehatan. Komunikasi kesehatan dilakukan untuk merubah perilaku individu, sosial dan organisasi. Komunikasi kesehatan harus direncanakan dengan baik dan kemudian setelah pelaksanaan perlu untuk dievaluasi agar dapat diketahui seberapa efektif komunikasi kesehatan yang telah dilakukan. Salah satu kerangka yang dapat digunakan untuk mengevaluasi komunikasi kesehatan adalah logic model. Model logika menghubungkan tujuan program, strategi, kegiatan, dan hasil dengan berbagai indikator dan fase pemantauan, penelitian, dan evaluasi (Schiavo, 2014). Berdasarkan hal tersebut, peneliti tertarik untuk mengkaji bagaimana komunikasi kesehatan tentang kesehatan reproduksi dan seksualitas di Youth Center PILAR PKBI Jawa Tengah ditinjau dengan Logic Model.

\section{METODE}

Penelitian kualitatif dengan desain penelitian studi kasus.Penelitian dilakukan selama bulan Januari sampai dengan Februari 2021 dengan sistem daring aplikasi whatsapp call dan zoom meeting dikarenakan situasi pandemi yang tidak memungkinkan pengambilan data secara tatap muka. Informan dari penelitian diambil secara purposive sampling (Arikunto, 2002). Peneliti melakukan pemilihan narasumber berdasarkan tujuan penelitian dan narasumber yang dianggap memiliki informasi yang dibutuhkan. Informan akan diberikan kode nama menjadi $\mathrm{A}, \mathrm{B}, \mathrm{C}$ dan seterusnya.

Metode pengumpulan data dilakukan dengan cara wawancara mendalam (WM) bersama 1 koordinator program PILAR dan 4 koordinator divisi untuk mendapatkan data terkait variabel input (sumber daya manusia dan keuangan), proses (strategi dan taktik), output (peer educator dan komitmen stakeholder). Kemudian untuk focus group discussion (FGD) dilakukan bersama 7 relawan PILAR dan 7 orang penerima manfaat program untuk mendapatkan data terkait variabel hasil (pengetahuan, sikap, dan perilaku). Pengumpulan data juga dilakukan dengan melihat website, akun sosial media, dan dokumentasi dari PILAR PKBI Jawa Tengah yang berupa laporan penelitian atau laporan agenda tahunan. 


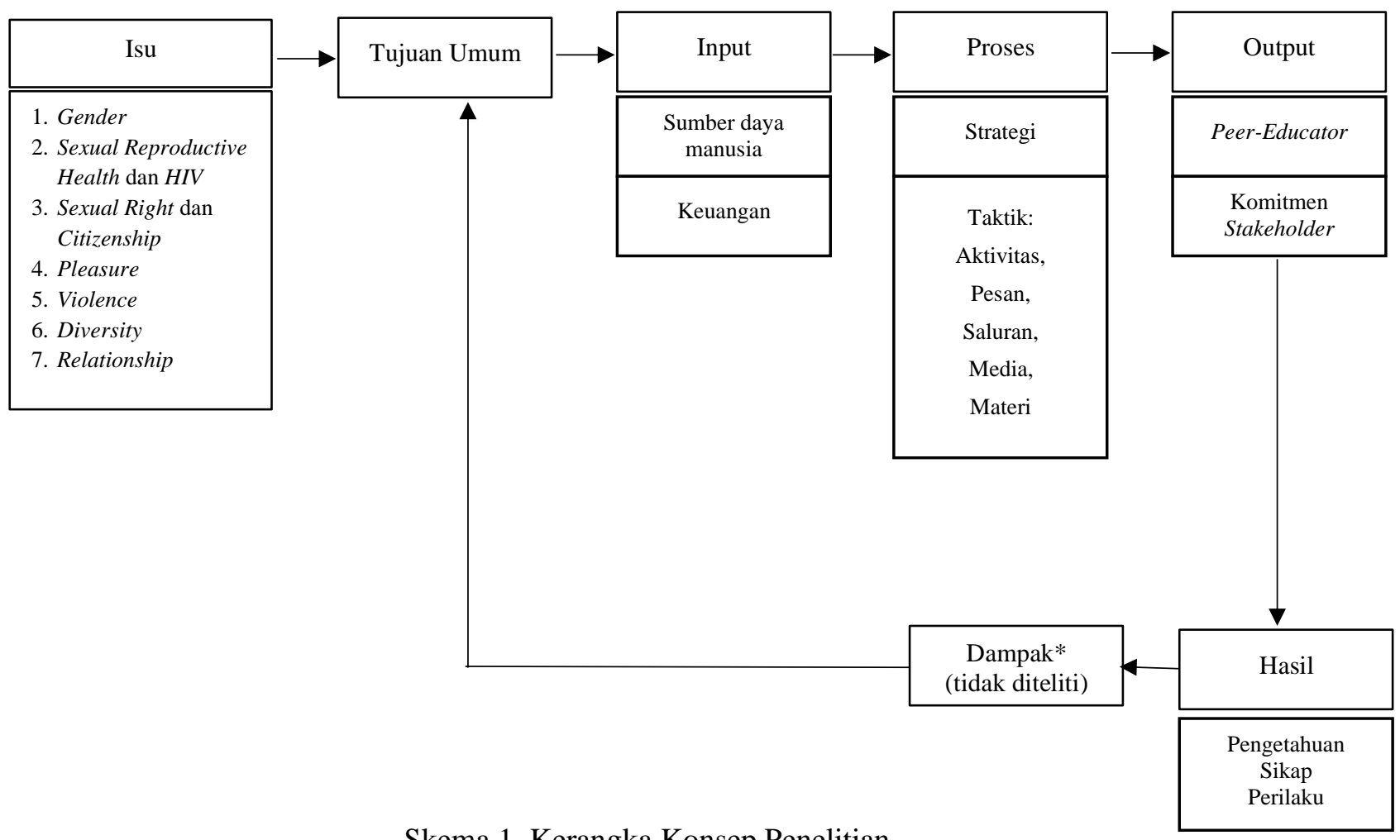

Skema 1. Kerangka Konsep Penelitian

Penelitian ini menggunakan analisis tematik. Etik penelitian menggunakan kaidah dalam Deklarasi Helsinki, menyampaikan informed consent kepada informan sebelum dilakukan WM atau FGD, serta meminta informan untuk tanda tangan surat pernyataan kesediaan.

\section{HASIL}

\section{Karakteristik Informan}

Informan penelitian berjumlah 19 orang. Informan ini terdiri dari koordinator program PILAR, divisi CSE, divisi CSS, divisi Youth Empowerment (YE), divisi Media Development (MD), divisi monev, relawan PILAR, dan penerima manfaat program PILAR (selengkapnya tersedia di tabel 1).

\section{Isu}

Isu yang disampaikan oleh PILAR kepada kelompok sasarannya terdiri dari gender, kesehatan reproduksi seksual dan HIV, hak seksual, kesenangan, kekerasan, perbedaan, dan hubungan. Semua informasi terkait CSE sudah disampaikan secara umum, namun belum dilakukan pendalaman materi pada kelompok sasaran. Kelompok sasaran PILAR adalah remaja berusia 10-24 tahun yang rentan karena rendahnya akses terhadap layanan informasi kesehatan seksual dan reproduksi baik remaja dengan pendidikan formal, informal, dan non formal serta marjinal.

\section{Tujuan}

Seperti yang telah tertera di laman website PILAR, disebutkan bahwa tujuan dari PILAR adalah meningkatkan kepedulian dan tanggung jawab remaja terhadap kesehatan seksual dan reproduksi, mengurangi penularan IMS dan HIV/AIDS, mencegah terjadinya kehamilan yang tidak diinginkan dengan meningkatkan pengetahuan remaja dan dukungan stakeholder. Tujuan tersebut kemudian diturunkan menjadi program dan kegiatan. Indikator keberhasilan yang digunakan PILAR yakni indikator kualitatif dan kuantitatif. 
Tabel 1. Karakteristik informan penelitian "Komunikasi Kesehatan tentang Kesehatan Reproduksi dan Seksual Komprehensif (Studi di Youth Center PILAR Jawa Tengah)" pada Bulan Februari 2021

\begin{tabular}{cccccc}
\hline Informan & Posisi & $\begin{array}{c}\text { Lama di } \\
\text { PILAR (th) }\end{array}$ & Status & $\begin{array}{c}\text { Jenis } \\
\text { kelamin }\end{array}$ & Usia (th) \\
\hline A & $\begin{array}{c}\text { Koordinator program dan } \\
\text { monev }\end{array}$ & 2 & Penuh waktu & P & 26 \\
B & Koordinator divisi CSE & 6 & Penuh waktu & P & 26 \\
C & Koordinator divisi CSS & 2 & Paruh waktu & P & 23 \\
D & Koordinator divisi YE & 5 & - & L & 27 \\
E & Koordinator divisi MD & 3 & Paruh waktu & P & 24 \\
F & Relawan & 2 & Divisi CSE & P & 22 \\
G & Relawan & 1 & Divisi YE & P & 20 \\
H & Relawan & 1 & Divisi CSE & P & 21 \\
I & Relawan & 3 & Divisi MD & L & 25 \\
J & Relawan & 2 & Divisi CSE & L & 23 \\
K & Relawan & 2 & Divisi CSE & P & 24 \\
L & Relawan & 2 & Divisi CSE & P & 23 \\
M & Remaja Sasaran & - & Siswa SMP & L & 16 \\
N & Remaja Sasaran & - & Siswa SMK & P & 16 \\
O & Remaja Sasaran & - & Siswa SMP & P & 15 \\
P & Remaja Sasaran & - & Siswa SMP & P & 14 \\
Q & Remaja Sasaran & - & Mahasiswa & P & 21 \\
R & Remaja Sasaran & - & Mahasiswa & P & 20 \\
S & Remaja Sasaran & - & Mahasiswa & P & 19 \\
\hline
\end{tabular}

“.......seberapa banyak remaja yang sudah mendapat akses informasi, seberapa banyak remaja yang udah dapat akses edukasi, kemudian ee berapa banyak remaja yang mengakses layanan kesehatan reproduksi ramah remaja, berapa apa yaa institusi sekolah sekian usia sekolah yang melembagakan HKSR di sekolah, berapa layanan ramah remaja yang sudah memberikan pelayanan di institusinya, bagaimana dukungan pemerintah dalam mendukung program-program HKSR. Kalo kuantitatifnya ya lebih ke progresnya bagaimana dari masing-masing akses edukasi, informasi dan layanan, dan dukungan pemerintah" - Informan A, 26 tahun

Program yang dilakukan oleh PILAR yakni Get Up Speak Up (bertujuan untuk meningkatkan akses dan informasi terkait pendidikan dan layanan kesehatan seksual dan reproduksi yang ramah remaja), Dance4Life (pendidikan seksualitas yang komprehensif melalui model pemberdayaan untuk remaja 13-19 tahun), Explore4Action (menggali dampak dari pendidikan seksualitas komprehensif yang difasilitasi oleh Rutgers WPF, yaitu SETARA (Semangat Dunia Remaja) bagi mereka), dan SobatASK (platform online sebagai saluran untuk mendukung penyampaian informasi mengenai Hak Kesehatan Seksual dan Reproduksi (HKSR) dan kekerasan bagi remaja). Selain itu, PILAR juga memiliki kegiatan yang telah dibagi kedalam masing-masing divisi yakni divisi edukasi (comprehensive sexual education), divisi layanan (comprehensive social service), divisi pemberdayaan (youth empowerment), divisi media (media 
development), dan divisi monitoring evaluasi.

\section{Input}

\section{Sumber daya manusia (SDM)}

Sumber daya manusia yang ada di PILAR terdiri dari 2 yakni staf dan relawan. Jumlah staf PILAR ada 8 orang yang terbagi ke dalam pagu koordinator program, koordinator divisi, bagian finance, dan bagian human resource. Sedangkan jumlah relawan ada 20 orang yang terbagi juga ke dalam masing-masing divisi. Staf dan relawan akan mendapatkan pelatihan baik dari PILAR maupun dari PKBI Jawa Tengah untuk meningkatkan kapasitas diri sebagai aktivis kesehatan reproduksi dan seksual remaja.

Berdasarkan hasil informasi dari relawan PILAR, mereka mendapatkan banyak jenis pelatihan kapasitas diri, yakni seperti public speaking, fasilitator sebaya (online maupun offline), konselor sebaya, penggunaan teknologi, value clarification, bekerja sama dengan tim, community organizer, cara konseling kelompok, dan lainnya.

\section{Keuangan}

PILAR mendapatkan pendanaan program dari Kementerian Luar Negeri Belanda, di Indonesia namanya Rutgers WPF Indonesia. Seperti program GUSO 2016-2020 dan Explore4Action 2019-2021. Berdasarkan informasi yang didapatkan dari informan, bahwa program Explore4Action merupakan program lanjutan dari GUSO. Dari sekian lembaga yang terlibat di program GUSO, hanya ada 3 lembaga yang berhasil melanjutkan kerjasama program dengan Rutgers WPF Indonesia, salah satunya adalah PILAR. Hal tersebut disampaikan informan karena pertimbangan progres dari program GUSO yang dilakukan kurang lebih 2 tahun di awal dan bagaimana komitmen pemerintah/stakeholder setempat. Pertanggung jawaban keuangan kepada pendonor (Rutgers WPF Indonesia) dilakukan setiap triwulan.

\section{Proses}

\section{Strategi}

Berdasarkan hasil wawancara informan strategi yang digunakan oleh PILAR untuk menginformasikan isu yang diangkat secara umum terdiri dari beberapa cara sesuai dengan sasaran yang dituju, seperti:

1. Kelompok remaja luar sekolah: pelatihan peer educator dan pendekatan vocal calling

“....ketika sudah menemukan anak anak yang sudah dipegang untuk jadi vocal calling lah untuk mengajak temen temanya gabung nah itu baru kayak gitu dan beberapa kali kita memang sempat cukup sering sih dating ke pilar diajak diskusi dan ikuitin pelatihan dari berbagai daerah..." - Informan D, 27 tahun

2. Kelompok remaja sekolah: kerjasama kegiatan dan pelatihan peer educator

3. Pemangku kebijakan: kerjasama kegiatan, lobbying anggaran, dan advokasi kebijakan.

\section{Taktik}

Dalam taktik yang dilakukan untuk mengkomunikasikan kesehatan reproduksi dan seksualitas, masing-masing divisi memiliki cara yang bervariasi.

\begin{abstract}
Aktivitas
Kegiatan rutin divisi CSE adalah edukasi daring dan luring, siaran radio, sharing knowledge relawan, program You\&Me PAUD, dan mengisi konten edukasi di Instagram yang disebut BUCIN. Untuk divisi CSS, kegiatan yang dilakukan adalah memberikan konseling kepada remaja baik online maupun offline. Sebelum pandemi juga melakukan pendataan remaja yang hamil dan yang sudah mengakses alat kontrasepsi di bidan. Selain itu juga terdapat
\end{abstract}


kegiatan pendampingan posyandu remaja dan pelatihan UKS. Konselor kadang juga memberikan konseling pada remaja yang sama sampai berkali-kali meskipun permasalahan sebelumnya belum selesai, sehingga terkadang konselor memberikan "pekerjaan rumah" pada remaja tersebut untuk menyelesaikan masalahnya dulu, baru kemudian menyampaikan perkembangannya ke konselor.

"...dari awal konsep konselor adalah bukan menyelesaikan masalah klien tapi membantu klien menyelesaikan permasalahannya seperti itu jadi biar nggak ketergantungan gitu” - Informan C, 23 tahun

Kegiatan divisi YE adalah mendampingi komunitas baik remaja sekolah maupun luar sekolah, yang kemudian dibentuk peer educator. Selanjutnya diadakan forumforum diskusi kesehatan reproduksi dan seksualitas. Selain itu, divisi ini juga memberikan tindak lanjut kepada sekolah yang tertarik bekerja sama dengan PILAR setelah mendapatkan edukasi dari divisi CSE.

"Program ya ada pelatihan, peningkatan kapasitas terus kampanye bersama kayak gitu....masalah alokasi anggaran kita juga dorong supaya mereka terlibat dalam musrembang pembangunan desa yang ada biasanya setiap tahun supaya mereka dapat alokasi dana dari kelurahan masing masing dan alhamduillah itu udah mereka dapat dana" - Informan D, 27 tahun

Kegiatan divisi MD adalah mengunggah konten edukasi remaja melalui media sosial, menjadi supporting program PILAR, berkolaborasi/media partner untuk komunitas remaja. Selain itu juga membuat pelatihan tentang penggunaan teknologi ke relawan PILAR yang kemudian merambah ke masyarakat umum. Untuk divisi monev, kegiatan yang dilakukan adalah penelitian, manajemen data konseling, dan informasi berdasarkan hasil penelitian dan konseling sebagai dasar advokasi.
Pesan

PILAR dalam website https://pilarpkbijateng.or.id/tentang-kami/ menyebutkan bahwa melalui program yang digagas diharapkan terwujud remaja yang sehat dan bertanggung jawab.

\section{Media dan Saluran}

Divisi CSE memberikan edukasi kesehatan reproduksi dan seksualitas menggunakan media massa (radio RRI, radio Imelda, dan radio streaming Dinas Pendidikan Provinsi Jawa Tengah), media baru (Instagram, Whatsapp, Zoom), dan media interpersonal (pertemuan tatap muka). Divisi CSS menerima konsultasi dengan beberapa jenis media baru (jejaring sosial: telegram, whatsapp, dan web PILAR yang memiliki fitur chat). Selama masa pandemi, konsultasi dilakukan secara online. Sedangkan sebelum pandemi, konsultasi pernah juga dilakukan dengan cara bertatap muka (media interpersonal). Divisi YE ini memberikan pemahaman tentang pentingnya kesehatan reproduksi dan seksualitas menggunakan media interpersonal (pertemuan tatap muka untuk diskusi, lobbying, dan advokasi ke lurah, bidan, dan stakeholder terkait).

“....karang taruna pasti dilibatkan di berbagai kegiatan Pilar kayak pertemuan di stakeholder bahkan tingkat kota Semarang waktu itu kita ketemu dengan pak sekda kita ajak karang taruna ketuanya, supaya mereka kita mau memperjuangkan mereka gak main main benar benar yang advokasi advokasi ke pemerintah mereka harus terlibat langsung.. " - Informan D, 27 tahun

Divisi MD mengelola beberapa media online untuk membagikan informasi terkait kesehatan reproduksi dan seksualitas, yakni instagram, website, youtube, podcast, dan tiktok. Instagram menjadi pusat publikasi semua konten yang ada di media PILAR lainnya. Website berisi tentang artikel yang tidak dapat diunggah di instagram dan berisi profil PILAR secara profesional. Youtube belum cukup dikembangan namun 
digunakan untuk membagikan video dan media untuk live saat sedang zoom. Podcast di inisiasinya tahun lalu sewaktu pandemi awal, topiknya hampir sama dengan di radio. Tiktok juga mulai dijadikan media edukasi, namun belum banyak unggahan kontennya karena memang baru diinisiasi.

\section{Materi}

Materi yang diberikan ketika edukasi di remaja sekolah dan non sekolah mengacu pada beberapa modul. Berdasarkan informasi informan, modul yang digunakan adalah untuk remaja SMP adalah modul SETARA disampaikan oleh guru BK yang terlatih untuk mengaplikasikan program kesehatan reproduksi, remaja SMA adalah modul Dance4Life disampaikan oleh relawan PILAR, dan remaja karang taruna adalah BERDAYA disampaikan oleh relawan PILAR juga.

"Modul yang dipakai bekerja sama dengan Rutgers, modul itu milik Rutgers, namun sebelum modul diberikan akan ada kontekstualisasi, bedah modul dan masingmasing temanya" - Informan B, 26 tahun

"Untuk materinya sesuai dengan modul yang sudah berkerja sama dengan kemendikbud dan kemenkes yang sudah benar-benar kolaborasikan isinya benarbenar sesuai dengan usianya dan karakternya sesuai dengan porsinya masingmasing”, - Informan D, 27 tahun

Selain materi untuk edukasi tatap muka (baik sebelum atau selama masa pandemi), terdapat pula materi yang disampaikan melalui media massa dan media baru.
“...Cuman bedanya tahun 2021 ini kami ada project Explore4Action yang pedesiminasi hasil penelitian itu jadi kita sekrang menambahkan data itu jadi kita misalkan ada data yang menarik dengan tema kampanye yang diangkat akan kita kembangkan jadi konten gitu" - Informan E, 24 tahun

\section{Tantangan}

Berdasarkan informasi dari informan, kendala yang sering didapati adalah merumuskan cara bagaimana dapat menjangkau seluruh sasaran dan membuat program yang spesifik sesuai dengan sasaran tersebut, isu kesehatan reproduksi yang kadang beberapa kelompok menganggap masih tabu, manajemen waktu relawan, komitmen dari remaja dampingan yang terkadang naik-turun, dan belum ada konsultan ahli materi yang dimiliki sendiri oleh PILAR sehingga terkadang meminta bantuan senior yang masih di PKBI maupun sudah keluar. Selain itu, selama masa pandemi ini, tantangan lain adalah sinyal untuk kegiatan virtual dan edukasi daring menggunakan aplikasi WhatsApp.

“....kebetulan kan aku ada di divisi cse yang iti kita menjadi fasilitator gitu kan. Dan kendalanya di aku adalah Ketika kita edukasi online adalah kan kadang kita selain dari zoom, gitu kan kita juga kadang ketikan gitu ya, ketikan melalui wa gitu, jadi kendala buat aku sampai sekarang itu sebenarnya apa ya, kayak kita itu susah edukasi lewat perantara... "-Informan H, 21 tahun

Tabel 2. Materi Modul Edukasi Kesehatan Reproduksi Dan Seksualitas Remaja

\begin{tabular}{ll}
\hline Nama Modul & Daftar Isi \\
\hline SETARA (kelas 7) & Perjalananku dimulai dari sini (3 topik), Aku dan \\
& Tubuhku (4 topik), Menuju kematangan (4 topik), \\
Memahami emosi (4 topik), Gender (2 topik), Hak dan \\
Pembuatan keputusan (3 topik), Aku dan orang-orang \\
di sekitar ku (4 topik), Aku saat ini (1 topik) \\
\hline
\end{tabular}




\begin{tabular}{|c|c|}
\hline Nama Modul & Daftar Isi \\
\hline SETARA (kelas 8) & $\begin{array}{l}\text { Pembukaan ( } 1 \text { topik), Relasi ( } 2 \text { topik), Gender ( } 1 \text { topik), Perilaku berisiko (1 } \\
\text { topik), Perilaku seksual ( } 1 \text { topik), Kehamilan ( } 3 \text { topik), IMS ( } 1 \text { topik), HIV- } \\
\text { AIDS ( } 1 \text { topik), Kekerasan ( } 3 \text { topik), Kesehatan Mental ( } 1 \text { topik), Teknologi, } \\
\text { Internet dan media sosial ( } 1 \text { topik), Napza ( } 1 \text { topik), Dukungan ( } 1 \text { topik), Cita- } \\
\text { cita ( } 1 \text { topik), Penutup }\end{array}$ \\
\hline $\begin{array}{l}\text { Dance4Life } \\
\text { Panduan Champions4Life }\end{array}$ & $\begin{array}{l}\text { Buku petunjuk Champions4Life, Undangan untuk bertransformasi, Aku, Aku } \\
\text { dan Kamu, Aku dan Masyarakat, Merayakan Transformasi }\end{array}$ \\
\hline BERDAYA & $\begin{array}{l}\text { Gender, Pubertas, Menstruasi dan mimpi basah, Organ seksual dan reproduksi } \\
\text { manusia, Perilaku seksual remaja dan risikonya, Mengemas pesan dan } \\
\text { menentukan media komunikasi }\end{array}$ \\
\hline
\end{tabular}

Tabel 3. Materi Edukasi Kesehatan Reproduksi Dan Seksualitas Remaja

\begin{tabular}{|c|c|c|}
\hline Media & Nama konten & Materi \\
\hline $\begin{array}{l}\text { Siaran Radio Imelda } \\
\text { 5-26 Maret } 2020\end{array}$ & $\begin{array}{l}\text { BIBIR (Bincang-bincang } \\
\text { remaja) }\end{array}$ & $\begin{array}{ll}\text { - } & \text { Belajar dari film parasite: fatwa orang kaya } \\
\text { dan miskin nikah } \\
\text { - } & \text { Candaan tubuh perempuan } \\
\text { - } & \text { Laki-laki juga dirugikan dari patriarki }\end{array}$ \\
\hline Siaran Radio Imelda & & Kekerasan Seksual dan Remaja \\
\hline 18 Februari 2021 & & \\
\hline Podcast PILAR & $\begin{array}{l}\text { K-POD } \\
\text { (Kespro Podcast) }\end{array}$ & $\begin{array}{l}\text { - Eps\#3: Yakin Catcalling cuma salahnya } \\
\text { cowok? } \\
\text { - Eps\#4: Seni mendampingi remaja masa } \\
\text { kini } \\
\text { - Dst }\end{array}$ \\
\hline Tiktok PILAR & & $\begin{array}{ll}\text { - } & \text { 4 Cara kurangin insecure } \\
\text { - } & \text { Tips tidur nyenyak } \\
\text { - } & \text { Yang dirawat saat \#dirumahaja } \\
\text { - } & \text { Tips meraih mimpi } \\
\text { - } & \text { dst }\end{array}$ \\
\hline Instagram & $\begin{array}{ll}\text { 1. } & \begin{array}{l}\text { Annyeong PILAR } \\
\text { (Belajar dari Drakor) }\end{array} \\
\text { 2. } & \text { Remaja Bersuara } \\
\text { 3. } & \text { BUCIN (Buat Cari } \\
\text { Informasi) } \\
\text { 4. Dan masih banyak lagi }\end{array}$ & $\begin{array}{ll}\text { - } & \text { Makna sebuah hubungan dari Love Scene } \\
\text { - } & \text { Pumber } \\
\text { - } & \text { dst } \\
\text { - } & \text { Perubahahan itu dimulai dari diriku } \\
\text { - } & \text { Kekerasan itu gak cuman fisik loh } \\
\text { - } & \text { Sebelum mencintai orang lain, yuk cintai } \\
\text { dirimu sendiri }\end{array}$ \\
\hline Zoom Meeting & $\begin{array}{l}\text { Remaja Disko } \\
\text { (Diskusi Kesehatan } \\
\text { Reproduksi) }\end{array}$ & - $\quad$ Backstreet online edisi pandemi \\
\hline Website & Artikel & $\begin{array}{l}\text { - Kenali dan Hindari Kekerasan dalam } \\
\text { Pacaran } \\
\text { - Buang sifat gak enakan: berani katakan } \\
\text { "tidak"Dst.. }\end{array}$ \\
\hline
\end{tabular}




\section{Output}

\section{Peer educator (PE)}

Berdasarkan informasi dari informan, untuk proses terbentuknya PE di sekolah dan universitas dampingan itu berbeda. PE di sekolah terbentuk karena inisiasi dari PILAR. Sedangkan di universitas karena beberapa dari mereka sudah menjadi unit kegiatan mahasiswa (UKM) maka PILAR berfungsi sebagai jejaring mereka dalam berkegiatan.

“.....kita ajak diskusi kelompok remaja yang sudah ada di sekolah kemudian kita advokasi ke guru dan kepala sekolah gitu ya untuk bisa mengadakan atau melembagakan peer educator ini, dan akhirnya beberapa berhasil yang seperti tadi mbak lihat di laporan program gitu...." - Informan A, 26 tahun

Fungsi dari PE disampaikan oleh informan yakni sama halnya dengan konselor sebaya yang dibentuk oleh pemerintah. PE di sekolah menjadi perpanjangan tangan dari guru untuk memberikan informasi, edukasi kepada teman teman sebayanya dan juga memberikan layanan kesehatan dan konseling yang dasar gitu kepada temannya pun dnegan peer educator universitas.

Jumlah organisasi PE dari PILAR di Kota Semarang yakni 20+ SMP/MTs, 5 SMA/SMK, 8 universitas, 5 karang taruna dan/komunitas. Selain jumlah organisasi PE yang telah terbentuk, terdapat beberapa pencapaian PILAR dalam memberikan edukasi kesehatan reproduksi dan seksualitas remaja, yakni:

a. Akses informasi dan pendidikan kesehatan reproduksi dan seksual komprehensif: 4 SMP/MTs piloting dan 22 perluasan, 5 SMA/SMK, 2 SLB, 65 guru terlatih PKRS, 7468 siswa mendapatkan PKRS, dan 250 remaja terlibat kampanye HKSR.

b. Dampingan posyandu remaja: Kelurahan Mangkang Kulon, Kelurahan Sekaran, dan Kelurahan Rowosari. c. Kolaborasi dengan pemerintah dalam penyusunan program kerja Tim Pembina UKS/M di Kota Semarang.

d. Advokasi berbasis data: 619.108 masyarakat terpapar informasi HKSR (online dan offline).

\section{Komitmen stakeholder}

Informan menyampaikan bahwa beberapa sekolah dampingan ada yang menjadikan kegiatan pendampingan ini sebagai ekstrakurikuler sehingga kepala sekolah mengeluarkan surat keputusan (SK). Ada pula yang meleburnya ke dalam ekstrakurikuler lainnya dengan dampingan dari guru yang terlatih Hak Kesehatan Seksual dan Reproduksi (HKSR). Selain itu, dukungan juga diberikan oleh sektor pemerintah seperti Dasar Nota Kesepahaman dengan Pemerintah Kota Semarang melalui Nota Kesepahaman Nomor 019.6/2/2018 pada 22 Februari 2018 tentang Penyelenggaraan Program Pendidikan Kesehatan Reproduksi dan Seksualitas (PKRS) serta perlindungan anak.

\section{Hasil}

Informan dapat memberikan informasi terkait isu dari kesehatan reproduksi dan seksual komprehensif. Isu yang pertama, Gender. Informan menyampaikan bahwa gender memiliki makna peran, sifat maskulin dan feminis, sifat/ perilaku yang dibedakan antara laki-laki dan perempuan, dan sifat/perilaku yang dibedakan oleh asumsi masyarakat. Ketujuh informan setuju dengan adanya kesetaraan gender. Semua informan telah mempraktekkan kesetaraan gender dalam hidupnya, salah satunya adalah menjadi ketua kelas.

"saya setuju ada kesetaraan, tidak semua perempuan harus dirumah kak, ada asumsi masyarakat kalo perempuan itu dirumah saja jadi irt dan laki laki harus kerja keras. Tapi itu ndak seharusnya begitu, perempuan bisa jadi apa saja, multi talent begitu untuk perempuan, ndak seimbang aja kalo cowok 
harus kerja keras tapi perempuan dirumah saja”- Informan O, 15 tahun

Isu kedua, HIV dan AIDS. Hampir semua informan mengetahui bahwa HIV adalah virus dan AIDS adalah penyakit yang disebabkannya. Semua informan mengetahui bahwa salah satu cara penularan HIV dan AIDS adalah dengan melakukan seks bebas. Beberapa informan juga tahu tentang Voluntary Counseling Test (VCT) digunakan untuk deteksi dini HIV. Ketujuh informan tidak setuju bila terjadi diskriminasi pada orang dengan HIV dan AIDS. Semuanya juga belum pernah melakukan test VCT.

“..jadi kalau odha kita perlakukan odha selayaknya sebagai teman sebagai manusia yg normal sebagai dia apa adanya..." Informan R, 20 tahun

Isu ketiga, Hak Seksual. Semua informan dapat menjelaskan bahwa setiap orang memiliki kebebasan dalam mengambil keputusan terkait masalah seksualnya. Semua informan tidak setuju bila terjadi perdagangan seksual manusia. Semua informan berpendapat bahwa cara untuk menghindari menjadi pelaku/korban perdagangan seksual manusia adalah dengan selektif memilih teman. Salah satu informan ada yang berpendapat untuk berhati-hati dalam mencari lowongan pekerjaan.

"Untuk mencegah jadi korban, bisa jadi lewat lowongan pekerjaan, iklan, dsb. Kita harus teliti lagi siapa yang menyebarkan, kerjanya bagaimana agar tidak tersesat dengan pilihan yang diambil. Kita harus teliti dan memiliki orang yang bisa dipercaya untuk tempat cerita sebagai bahan pertimbangan" - Informan R, 20 tahun

Isu keempat, Kekerasan. Hampir semua informan dapat memberikan penjelasan tentang bentuk-bentuk kekerasan dan semua informan dapat menjelaskan tentang toxic relationship. Beberapa informan berpendapat bila ingin terhindar dari toxic relationship adalah dengan mencintai diri sendiri.

“...mengerti diri kita dulu, menghargai orang lain intinya juga berbuat baik kepada orang lain tetapi juga kita dapat membentengi diri kita, lebih selektif, berani ambil sikap, bila perlu telfon polisi / orang yang bisa dihubungi" - Informan S, 19 tahun

\section{PEMBAHASAN}

Isu

Edukasi tentang kesehatan reproduksi dan seksualitas yang komprehensif (comprehensive sexual education) harus dapat menyampaikan tujuh materi yakni tentang Gender, Sexual Reproductive Health dan HIV, Sexual Right dan Citizenship, Pleasure, Violence, Diversity, dan Relationship (IPPF, 2010).

\section{Tujuan}

Tujuan yang ditentukan perlu mencerminkan dan konsisten dengan topik yang akan disampaikan, dalam hal ini topik yang dimaksud adalah isu kesehatan. Faktor keberhasilan dalam mencapai tujuan komunikasi juga harus memperhatikan hasil analisis komunitas dan pengalaman kelompok kunci serta mengambil pembelajaran dari intervensi masa lalu. Analisis faktor-faktor tersebut adalah relevan terutama untuk pengembangan strategi komunikasi dan rencana taktis (Schiavo, 2014). PILAR mengangkat isu dalam program komunikasi kesehatan adalah tentang kesehatan reproduksi dan seksual komprehensif pada remaja di Kota Semarang. Isu tersebut telah terlihat dalam tujuan yang dirumuskan. Selanjutnya proses pelaksanaan komunikasi kesehatan memperlihatkan bagaimana PILAR dapat mendekati kelompok sasaran yang berbeda dengan strategi dan taktik yang berbeda pula.

\section{Input}

Sumber daya manusia 
Dalam pelaksanaan program kesehatan, diperlukan sumber daya manusia yang dapat diandalkan untuk melaksanakan program dan mencapai tujuan yang telah ditetapkan bersama. Strategi dan taktik yang disusun untuk dilaksanakan, tidak akan berjalan dengan baik bila SDM yang ada tidak cukup terlatih. Selain itu, kapasitas SDM yang memadai akan memberikan daya tawar lebih pada organisasi pendonor (Suciati, 2018).

Peningkatan kapasitas merupakan proses yang dapat membantu suatu program atau organisasi untuk mencapai visinya, strategi, sistem, infrastruktur, dan sumber daya manusia untuk melayani kebutuhan masyarakat dengan lebih baik (Corporation for National and Community Service, no date). Penelitian yang dilakukan oleh VSO Nepal menyebutkan bahwa relawan harus menerima pelatihan tentang kemampuan memfasilitasi, bagaimana berbicara kesehatan reproduksi dan seksual kepada remaja, sistem peer education, dan isu kesehatan reproduksi yang sensitif, rahasia, dan tidak menghakimi sebelum melakukan program (Hacker, 2015). Penelitian lain tentang kapasitas relawan dilakukan pada isu End of Life Care (EoLC) yakni didapatkan hasil bahwa 4 tahap yang dapat dilakukan dalam program peningkatan kapasitas relawan, yakni skrining motivasi, pelatihan kompetensi dasar, magang, dan dalam pemantauan, secara efektif memberdayakan relawan dalam menyediakan EoLC untuk orang tua di komunitas mereka (Wang, Chan and Lou, 2020).

Dalam penelitian ini, PILAR sudah cukup banyak memberikan program peningkatan kapasitas untuk relawannya. Bahkan permintaan pelatihan keterampilan yang dibutuhkan oleh relawan juga dapat diberikan. Terlihat juga dari hasil wawancara, bahwa relawan merasa terfasilitasi dalam hal pengembangan diri dan merasa lebih terampil dalam penyampaian isu kesehatan reproduksi dan seksual remaja.

\section{Keuangan}

Selain SDM, sebelum pelaksanaan program perlu dipastikan terlebih dahulu anggaran yang dapat digunakan. Anggaran dana merupakan hal yang krusial dalam tahap perencanaan program karena anggaran tersebut yang akan digunakan dalam pelaksanaan program (Kusuma, 2017). Dalam sebuah laporan penelitian disebutkan beberapa sumber dana untuk keberlanjutan finansial LSM di Indonesia yakni dari lembaga internasional, dana swadaya, dana pemerintah, dana pihak swasta dan filantropi (Davis, 2020).

Program PILAR yang berkelanjutan dan berasal dari pendonor internasional yang sama salah satunya yakni GUSO 2016-2020 yang kemudian dilanjutkan ke program Explore4Action 2021. Hal ini diakui oleh informan karena pencapaian program GUSO yang dirasa baik oleh pihak pendonor.

\section{Proses}

\section{Strategi}

Pencapaian program yang baik dapat dilihat dari bagaimana proses yang telah dilakukan. Dalam penelitian ini proses terbagi menjadi dua hal yakni strategi dan taktik. Strategi dan taktik yang digunakan telah disesuaikan dengan kelompok sasaran. Untuk remaja menggunakan pelatihan peer educator dan tambahan untuk remaja luar sekolah dengan menggunakan pendekatan vocal calling, sedangkan untuk pemangku kebijakan yakni dengan kerjasama kegiatan, lobbying, dan advokasi kebijakan.

Pendidikan kesehatan seksual yang dipimpin oleh sebaya merefleksikan efek yang positif baik di sekolah, rumah, maupun masyarakat dan program tersebut menginspirasi pendidik sebaya untuk menjadi agen perubahan komunitas mereka di luar pelaksanaan proyek (Benton et al., 2020). Penelitian lainnya menyebutkan bahwa dampak pelatihan peer educator kesehatan reproduksi dan seksual yang terstruktur dengan baik dapat meningkatkan pengetahuan relawan mahasiswa kedokteran dan membuat perubahan sikap yang positif (Ozaydin et al., 2020). Remaja dapat 
diberdayakan menjadi advokat, peneliti, pendidikan, dan penyedia layanan (Rufurwadzo et al., 2020).

Strategi lobbying biasanya digunakan untuk mengubah peraturan atau menambahkan peraturan atau memperoleh pendanaan yang dapat sukses bila melakukan 11 hal yakni anticipation and early warning, good position, concentrated intelligence, problem/solution, grassroots mobilization, working the process, coalitions, personal contact, attention to detail, consistent pressure, and judgment (Christian, 2015). Sementara strategi advokasi digunakan spesifik untuk mengubah kebijakan, posisi, atau program dalam segala macam organisasi. Untuk mencapai advokasi yang sukses juga perlu memperhatikan beberapa hal yakni koalisi, tujuan, data, sasaran, pesan, presentasi, dan evaluasi (Sharma, n.d).

\section{Taktik}

Taktik yang dilakukan dalam melaksanakan implementasi program komunikasi kesehatan reproduksi berbentuk aktivitas per divisi, pesan, media dan saluran, serta materi. Divisi yang ada sangat menguntungkan dalam proses komunikasi kesehatan. Divisi CSE memberikan edukasi kesehatan reproduksi, kemudian ditindaklanjuti oleh divisi YE untuk melakukan pemberdayaan remaja. Sementara bila ada remaja ingin curhat atau konsultasi terkait kesehatan reproduksi dan seksual akan dibantu oleh divisi CSS. Tidak lupa pula PILAR menjangkau remaja yang lebih luas lagi dengan media baru (online) yang dikelola oleh divisi media.

Berdasarkan hasil penelitian terdahulu, edukasi yang diberikan dengan materi dan metode yang berbeda mendapatkan hasil pengetahuan yang berbeda pula (Sihite, Nugroho and Dharmawan, 2017). PILAR memberikan edukasi kepada remaja sekolah dan luar sekolah dengan topik materi yang berbeda dan metode pendekatan yang berbeda pula disesuaikan dengan sasaran. Edukasi kesehatan merupakan kesempatan yang dibangun secara sadar untuk belajar yang melibatkan beberapa bentuk komunikasi dan dirancang untuk meningkatkan literasi kesehatan, termasuk meningkatkan pengetahuan, dan mengembangkan keterampilan hidup, yang kondusif bagi kesehatan individu dan masyarakat (WHO, 2012).

Media dan saluran komunikasi yang digunakan PILAR sangat beragam. Media massa menyediakan hubungan penting di antara penduduk pedesaan dan informasi kesehatan yang penting. Media massa berupa radio dan televisi adalah cara yang efektif untuk membujuk khalayak sasaran untuk mengadopsi perilaku baru, atau untuk mengingatkan mereka tentang informasi penting (Naveena, 2015). Komunikasi melalui media sosial telah menghasilkan keluaran yang positif dalam penyebaran informasi di setiap aspek kehidupan, termasuk kesehatan. Salah satu fungsi media sosial adalah mendukung pembangunan dengan memberdayakan masyarakat dalam menjaga kesehatan dan kesejahteraannya. Media sosial merupakan media yang paling banyak digunakan remaja dalam mencari informasi kesehatan reproduksi (Setianti et al., 2017). Beberapa implikasi dari keterlibatan media sosial untuk komunikasi kesehatan meningkat dan direkomendasikan untuk masa depan (Heldman, Schindelar and Weaver, 2013). Namun terdapat juga media sosial yang berpotensi untuk menimbulkan mispersepsi, yakni Twitter (Suarez-Lledo and Alvarez-Galvez, 2021). Informasi yang salah tentang kesehatan memiliki konsekuensi yang sangat parah yang berkaitan dengan kualitas hidup masyarakat dan bahkan berisiko kematian. Oleh karena itu, memahami media sosial dalam konteks modern saat ini adalah tugas yang sangat penting (Swire-Thompson and Lazer, 2019).

\section{Output \\ Peer Educator}

PILAR juga melakukan pemberdayaan remaja dalam bidang kesehatan reproduksi dan seksual. Pemberdayaan adalah proses 
meningkatkan kapasitas orang untuk membuat pilihan independen dan mampu menerapkan pilihan tersebut dalam praktik, karenanya tidak hanya bergantung pada orang atau orang-orang yang membuat pilihan, tetapi juga tentang lingkungan yang menawarkan pilihan yang sesuai (Naidoo and Wills, 2006). Bentuk pemberdayaan yang dilakukan PILAR adalah dengan membentuk peer educator. Peer Educator merupakan seseorang yang tinggal dalam kelompok sosial yang sama dengan orang lain dengan membawa misi mengacu pada pengembangan pengetahuan, sikap, keyakinan, atau perilaku seseorang sebagai hasil dari proses pembelajaran (UNFPA, 2011). Konselor sebaya yang dibentuk dan dilatih menjadi sebuah upaya yang tepat untuk membekali remaja dengan hal-hal positif sehingga dapat terhindar dari pengaruh negatif lingkungan (Sarmin, 2017).

\section{Komitmen Stakeholder}

Untuk menjamin keberlangsungan program komunikasi kesehatan yang telah dilaksanakan, maka perlu adanya kebijakan terkait program tersebut. Pada umumnya kebijakan disahkan oleh pimpinan tertinggi dari sebuah lembaga atau organisasi. Kepala sekolah menjadi pemimpin tertinggi di sekolah. Sebuah penelitian menyebutkan bahwa dukungan sekolah berupa kebijakan, sarana, dan pelaksanaan merupakan faktor pendukung/enabling dari guru untuk memberikan materi kesehatan reproduksi (Juariah and Irianto, 2020). Selain itu, pemerintah merupakan penggerak utama dalam isu kesehatan reproduksi remaja. Hal ini karena pemerintah memiliki kewenangan birokrasi, bersifat formal, dan memiliki sumber keuangan (Jati dan Suryoputro, 2016).

\section{Hasil}

Hasil yang diharapkan dari sebuah program komunikasi kesehatan untuk individu yakni terjadi perubahan pengetahuan, sikap, dan perilaku (Schiavo, 2014). Pendidikan kesehatan reproduksi dapat meningkatkan pengetahuan remaja tentang kesehatan reproduksi (Budi Widiyanto, Purnomo and Sari, 2013) dan sikap remaja (Oktarina, Marono and Purnomo, 2017). Penelitian lain menyebutkan bahwa pendidikan seksual memberikan dampak baik pada psikologis ketahanan perilaku seks remaja (Rinta, 2015).

\section{KESIMPULAN}

Youth Center PILAR PKBI Jawa Tengah memiliki konsentrasi isu kesehatan reproduksi dan seksual remaja dan telah sesuai dengan konsep Comprehensive Sexual Education yakni gender, kesehatan reproduksi seksual dan HIV, hak seksual, kesenangan, kekerasan, perbedaan, dan hubungan. Tujuannya adalah untuk meningkatkan kepedulian dan tanggung jawab remaja terhadap kesehatan reproduksi dan seksual. Input yang dimiliki untuk melakukan program komunikasi kesehatan yakni SDM/relawan terlatih dan sumber dana yang memadai dari pendonor. Proses yang dilakukan cukup kompleks. Strategi yang dilakukan terdiri dari pelatihan peer educator, pendekatan vocal calling, kerjasama kegiatan, lobbying, dan advokasi stakeholder. Sedangkan taktik dalam komunikasi kesehatan reproduksi yang dilakukan mulai dari aktivitas edukasi, pemberdayaan remaja, konsultasi, dan pengelolaan media edukasi (online atau offline). Kemudian penggunaan media dan saluran yang bervariasi dan penentuan pesan kunci yang disampaikansecara bersamasama yakni remaja sehat dan bertanggung jawab. Output dari komunikasi tersebut yakni terbentuknya peer educator dan adanya dukungan/komitmen dari stakeholder. Hasil dari program komunikasi yang dilakukan secara kualitatif menggambarkan bahwa pengetahuan, sikap, dan perilaku kelompok sasaran sudah cukup baik mengenai isu kesehatan reproduksi dan seksualitas. Rekomendasi untuk PILAR yakni membuat pelatihan relawan dan peer 
educator lebih terstruktur sesuai dengan 4 tahapan peningkatan kapasitas yakni skrining motivasi, pelatihan kompetensi dasar, magang, dan dalam pemantauan sehingga harapannya relawan dapat lebih maksimal belajar dan lebih terarah dalam penguasaan metode maupun materi edukasi.

\section{UCAPAN TERIMAKASIH}

Peneliti mengucapkan terima kasih banyak kepada seluruh informan yang telah bersedia meluangkan waktu untuk memberikan informasi dalam penelitian ini.

\section{DAFTAR PUSTAKA}

Amare, H. (2017) 'Risky Sexual Behavior and Associated Factors Among Adolescent Students in Tana Haik High School, Bahir Dar, Northern Ethiopia', International Journal of HIV/AIDS Prevention, Education and Behavioural Science, 3(4), p. 41. doi: 10.11648/j.ijhpebs.20170304.12.

Arikunto, S. (2002) Metode Penelitian. Jakarta: PT. Bina Aksara.

Azinar, M. et al. (2018) 'Youth Centre Model Peningkatan Pengetahuan dan Sikap Remaja di Daerah Tinggi Kehamilan Berisiko', HIGEIA JOURNAL OF PUBLIC HEALTH RESEARCH AND DEVELOPMENT, 2(4), pp. 663-672.

Benton, A. D. et al. (2020) 'Peer-Led Sexual Health Education: Multiple Perspectives on Benefits for Peer Health Educators', Child and Adolescent Social Work Journal, 37(5), pp. 487-496. doi: 10.1007/s10560-020-00661-9.

BKKBN (2019) Modul Keluarga-Hasil Survei Kinerja Dan Akuntabilitas Program Kkbpk (Skap) Tahun 2019.

Brayboy, L. M. et al. (2018) 'The use of technology in the sexual health education especially among minority adolescent girls in the United States HHS Public Access', Curr Opin
Obstet Gynecol, 30(5), pp. 305-309. doi:

10.1097/GCO.0000000000000485.

Budi Widiyanto, Purnomo and Sari, A. M. (2013) 'Pengaruh Pemberian Pendidikan Kesehatan Reproduksi Remaja terhadap Pengetahuan tentang Perilaku Seksual', Jurnal Keperawatan Komunitas, 1(2), pp. 101-107.

Christian (2015) 11 ELEMENTS OF SUCCESSFUL LOBBYING | Association of Accredited Public Policy Advocates to the European Union. Available at: http://www.aalep.eu/11-elementssuccessful-lobbying (Accessed: 5 March 2021).

Corporation for National and Community Service (no date) 'Toolkit for Program Sustainability, Capacity Building, and Volunteer Recruitment / Management', pp. 1-45. Available at: http://www.nationalserviceresources.o rg/filemanager/download/online/sustai nability_toolkit.pdf.

Davis, B. (2020) Keberlanjutan Finansial dan Diversifikasi Pendanaan: Tantangan bagi LSM Indonesia. Available at: https://www.ksiindonesia.org/id/pengetahuan/detail/1 019-nssc-publication-research-series2-keberlanjutan-finansial-dandiversifikasi-pendanaan-tantanganbagi-lsm-indonesia-oleh-ben-davis.

Hacker, E. (2015) 'Youth Volunteering contribution to sexual reproductive health development results in Baglung', (July).

Heldman, A. B., Schindelar, J. and Weaver, J. B. (2013) 'Social Media Engagement and Public Health Communication: Implications for Public Health Organizations Being Truly "Social", Public Health Reviews, 35(1), pp. 1-18. Available at: https://search.proquest.com/docview/1 464737561 ? accountid $=17242$.

IPPF (2010) 'IPPF Framework for 
Comprehensive Sexuality Education', London: International Planned Parenthood Federation, (January), p. 6. Available at: http://www.ippf.org/sites/default/files/ ippf_framework_for_comprehensive_ sexuality_education.pdf.

Jati, S. P. and Suryoputro, A. (2016) 'Stakeholder Pemerintah Sebagai Prime Mover Keberhasilan Jejaring Pelayanan Kesehatan Peduli Remaja', Indonesian Journal of Health Promotion, 9(1), pp. 45-55. doi: 10.14710/jpki.9.1.45-55.

Juariah, J. and Irianto, J. I. (2020) 'Peran Dan Faktor Yang Berhubungan Dengan Perilaku Guru Dalam Pendidikan Kesehatan Reproduksi Remaja Sekolah Menengah Pertama Di Kabupaten Subang Tahun 2019', Jurnal Kesehatan Reproduksi, 11(1), pp. 11-24. doi: 10.22435/kespro.v11i1.3092.

Kasim, F. (2014) 'Dampak Perilaku Seks Berisiko terhadap Kesehatan Reproduksi dan Upaya Penanganannya (Studi tentang Perilaku Seks Berisiko pada Usia Muda di Aceh)', Jurnal Studi Pemuda, 3(1), pp. 39-48. Available at: https://jurnal.ugm.ac.id/jurnalpemuda/ article/download/32037/19361.

Kemenkes RI (2017) Survey Demografi dan Kesehatan Indonesia, Survei Demografi dan Kesehatan Indonesia 2017.

Kusuma, A. (2017) Manfaat Penyusunan Anggaran dalam Organisasi NirlabaIntegrasi Edukasi. Available at: http://www.integrasi-

edukasi.org/manfaat-penyusunananggaran-dalam-organisasi-nirlaba/ (Accessed: 4 March 2021).

Naidoo, J. and Wills, J. (2006) 'Public Health and Health Promotion: Developing practice', Health Promotion Journal of Australia, 17(2), pp. 153-153. doi: 10.1071/he06153.

Naja, Z. S., Agushybana, F. and Mawarni, A.
(2017) 'Hubungan Pengetahuan, Sikap Mengenai Seksualitas Dan Paparan Media Sosial Dengan Perilaku Seksual Pranikah Pada Remaja Di Beberapa SMA Kota Semarang Triwulan II Tahun 2017', JURNAL KESEHATAN MASYARAKAT (e-Journal), 5(4), pp. 282-293.

Naveena, N. (2015) 'Importance of Mass Media in Communicating Health Messages: An Analysis', IOSR Journal Of Humanities And Social Science, 20(2), pp. 36-41. doi: 10.9790/0837-20253641.

Oktarina, J., Marono, H. M. and Purnomo, W. (2017) 'Pengaruh Pendidikan Kesehatan Reproduksi oleh Sebaya Terhadap Pengetahuan dan Sikap dalam Pencegahan Seks Pranikah di SMAN 1 Sukamara, Kabupaten Sukamara, Kalimantan Tengah', Buletin Penelitian Sistem Kesehatan, 20(1). doi: 10.22435/hsr.v20i1.6180.26-33.

Ozaydin, A. N. et al. (2020) 'The impact of training of peer educator on sexual and reproductive health: An interventional study', Marmara Medical Journal, 33(2), pp. 75-82. doi: 10.5472/marumj.738403.

Pusat dan Informasi Layanan Remaja PKBI (no date). Available at: https://pkbi.or.id/program/pusat-daninformasi-layanan-remaja/ (Accessed: 27 January 2021).

Rinta, L. (2015) 'Pendidikan Seksual Dalam Membentuk Perilaku Seksual Positif Pada Remaja Dan Implikasinya Terhadap Ketahanan Psikologi Remaja', Jurnal Ketahanan Nasional, 21(3), p. 163. doi: $10.22146 / \mathrm{jkn} .15587$.

Rufurwadzo, T. G. et al. (2020) 'Young people are experts and leaders in the HIV response', Journal of the International AIDS Society, 23(S5), pp. 13-14. doi: 10.1002/jia2.25569.

Sarmin (2017) 'Konselor Sebaya: Pemberdayaan Teman Sebaya Dalam 
Sekolah Guna Menangulangi Pengaruh Negatif Lingkungan', BRILLIANT: Jurnal Riset dan Konseptual, 2(1), pp. 102-112.

Schiavo, R. (2014) Health Communication from Theory to Practice. Second Edi. San Fransisco: Jossey-Bass.

Setianti, Y. et al. (2017) 'Social Media and Reproductive Health - Communication Model of Adolescent Reproductive Health in Social Media', KnE Social Sciences, 2(4), p. 28. doi: 10.18502/kss.v2i4.864.

Sharma, R. R. An Introduction to Advocacy: Training Guide, U.S. Agency for International Development, Africa Bureau, Office of Sustainable Development. doi: 10.1016/S00223182(97)70237-1.

Sihite, P., Nugroho, D. and Dharmawan, Y. (2017) 'Pengaruh Edukasi Kesehatan Reproduksi terhadap Pengetahuan Siswa tentang TRIAD KRR (Seksualitas, HIV/AIDS, dan NAPZA) di SMK SWADAYA Kota Semarang Triwulan II Tahun 2017 |', JURNAL KESEHATAN MASYARAKAT (eJournal), 5(4), pp. 237-246. Available at:

https://ejournal3.undip.ac.id/index.ph p/jkm/article/view/18355/17435

(Accessed: 5 March 2021).

Suarez-Lledo, V. and Alvarez-Galvez, J. (2021) 'Prevalence of health misinformation on social media: Systematic review', Journal of Medical Internet Research, 23(1). doi: 10.2196/17187.

Suciati, R. (2018) 'Kendala Organisasi Berbasis Komunitas dalam Program Pencegahan dan Penanggulangan HIV
/ AIDS : Studi Kasus pada Dua LSM Peduli AIDS di Jakarta Community Based Organizations ' Constraints in HIV / AIDS Prevention Program: Case Study on Two NGOs Cares Aids', Jurnal Penelitian dan Pengembangan Pelayanan Kesehatan, 2(3), pp. 163-174.

Swire-Thompson, B. and Lazer, D. (2019) 'Public health and online misinformation: Challenges and recommendations', Annual Review of Public Health, 41, pp. 433-451. doi: 10.1146/annurev-publhealth-040119094127.

Umaroh, A. K., Kusumawati, Y. and Kasjono, H. S. (2017) 'Hubungan Antara Faktor Internal Dan Faktor Eksternal Dengan Perilaku Seksual Pranikah Remaja Di Indonesia', Jurnal Kesehatan Masyarakat Andalas, 10(1), p. 65 . doi: 10.24893/jkma.10.1.65-75.2015.

UNFPA (2011) Youth peer education toolkit: Training of trainers manual. Available at: http://www.unfpa.org/webdav/site/glo $\mathrm{bal} / \mathrm{shared} /$ documents/publications/20 06/ypeer_tot.pdf.

Wang, Q., Chan, I. K. W. and Lou, V. W. Q. (2020) 'Effectiveness of a Holistic Capacity-Building Program for Volunteers in CommunityBased Endof-Life Care', Research on Social Work Practice, 30(4), pp. 408-421. doi: $10.1177 / 1049731519898530$.

WHO (2012) Health education: theoretical concepts, effective strategies and core competencies A foundation document to guide capacity development of health educators. 
